\title{
Mycological study for a management plan of a neotropical show cave (Brazil)
}

\author{
Erika Linzi Silva Taylor ${ }^{1 *}$, Maria Aparecida de Resende Stoianoff ${ }^{2}$, \\ and Rodrigo Lopes Ferreira ${ }^{3}$

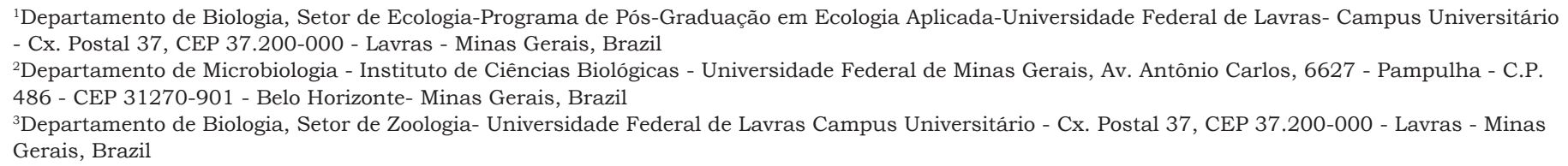
Gerais, Brazil

\begin{abstract}
Caves are stable environments with characteristics favoring the development of microorganisms. The allocthonous input of organic matter and microbes into the warm Neotropical caves may favor the development of filamentous fungi, including pathogenic species. Histoplasma capsulatum is a pathogenic species commonly found in caves and associated with bat and bird guano. Many Brazilian caves have been historically visited due to scenic and religious tourism. The objective of this study was to perform a microbiology study for a management plan of a show cave in Brazil, focusing on the presence and distribution of pathogenic and opportunistic fungi in the cave. Statistic analysis was used to verify the influence of touristic activity on airborne fungi spore load. Fungi were isolated from air and guano in Lapa Nova Cave. Samples were obtained through serial dilution, direct and settle plate techniques. For $H$. capsulatum, samples were incubated in specific media and conditions. Airborne fungal spore load was compared prior and during visitation and statistically analyzed. A total of 2,575 isolates from the genera Aspergillus, Calcarisporium, Chaetomium, Cladosporium, Curvularia, Emericella, Eurotium, Fusarium, Geotrichum, Gliocladium, Mucor, Purpureocillium, Paecilomyces, Penicillium, Rhizopus and Trichoderma were identified. Histoplasma capsulatum was not isolated from the cave. Eleven opportunistic species were identified. Significant $(p<0.05)$ variations on fungal richness in the air occurred due to cave visitation. Areas of potential microbiologic risks were indicated and management actions suggested. The results suggest a diverse community inhabiting the cave. Possible opportunistic species should be monitored in show caves and microbiota should always be included in the elaboration of cave management plans. This is the first detailed microbiologic study for a management plan of a show cave in the country. It provides relevant information for future management plans.
\end{abstract}

Keywords: cave; pathogenic fungi; microbiology; management plan; cave tourism

Received 22 April 2013; Revised 18 September 2013; Accepted 23 September 2013

Citation: Taylor E.L.S, Resende-Stoianoff M.A.A. and Lopes Ferreira R., 2013. Mycological study for a management plan of a neotropical show cave (Brazil). International Journal of Speleology, 42 (3), 267-277. Tampa, FL (USA) ISSN 0392-6672 http://dx.doi.org/10.5038/1827-806X.42.3.10

\section{INTRODUCTION}

Caves are stable environments characterized by high humidity, constant temperature and absence of light (Poulson \& White, 1969; Culver, 1982). The subterranean ecosystem generally holds a distinctive biota. Microbes are part of cave biodiversity and play an important ecological role. They may serve as food resources for invertebrate communities (Sarbu, 1996; Porter, 2009; EstradaBárcenas et al., 2010), be involved in nutrient cycling (Griffin, 1994; Engel et al., 2004; Porter et al., 2009) and may control the populations of some invertebrates (Gunde-Cimerman et al., 1998; Yoder et al., 2009).

*taylor.els@gmail.com
The touristic and religious use of caves is frequent in Brazil. The religious use generally involves the construction of chapels, shrines and even churches at the cave entrances (Souza-Silva, 2008). However, cave visitation may have serious impact on the hypogean system, such as: 1) enrichment of the environment by organic and inorganic matter left by visitors, 2) change of pristine climate (e.g. temperature, concentration of carbon dioxide, humidity), 3) stepping on fauna and microbiota, 4) compacting of soil (Pulido-Bosch et al., 1997; Barton, 2006; Barton \& Northup, 2007) and 5) altering cave biodiversity distribution and composition. 
Touristic activities may favor the dispersion and import of new microbes (Barton, 2006). This could lead to fungal outbreaks including potential pathogenic species and causing tourists innumerous health problems (Cury et al., 2001).

Caves harbor a diverse array of fungi which may include pathogenic and opportunistic species. Opportunistic fungal infections have become more and more frequent in past decades, mainly due to the increasing number of immunosuppressing therapies and emerging diseases (Armstrong, 1989; Pfaller \& Diekema, 2004). The number of fungi reported to cause opportunistic infections has been increasing in the past decades. The genera Aspergillus, Penicillium, Paecilomyces, Purpureocillium, Fusarium and Candida have been frequently reported as causative agents (Armstrong, 1989; Pfaller \& Diekema, 2004; Trabulsi \& Alterthum, 2004). Some opportunistic species are even related to fatal opportunistic infections in immunosuppressed people.

Concerning the true fungal pathogens (fungi capable of causing disease in immunocompetent organisms) inhabiting subterranean environments, special attention has been given to the thermo-dimorphic fungus Histoplasma capsulatum. This species causes histoplasmosis, which is a serious respiratory and systemic infection (Gompertz et al., 2004; Guimarães et al., 2006). The symptoms range from mild sickness (often mistaken with a more serious flu) to disseminated infection and death. It may affect both immunocompromised and immunocompetent individuals, with severity usually related to personal immune response (Woods, 2002; Gompertz et al., 2004; Guimarães et al., 2006).

Histoplasma capsulatum is commonly found in its filamentous form in the environment. It grows in locations rich in nitrogen (guano and soil) and $\mathrm{pH}$ higher than 5 (Mahvi, 1970; Carvajal-Zamora, 1977; Trabulsi \& Alterthum, 2004) and produces macroand microconidia. Infection occurs by inhalation or contact with microconidia. Cave visitation may cause conidial suspension and expose visitors to possible infection (Ashford et al., 1999; Lyon et al., 2004). Cases of histoplasmosis have been linked with cave visitation in Brazil (Cury et al., 2001). However, many cases are commonly misdiagnosed and treated as bacterial pneumonia, flu or allergy.

The environmental legislation concerning touristic and economic use of caves has been changing in Brazil in the past decade (CECAV/IBAMA, 2009). Management plans are now required by the government prior to touristic use of any caves in national territory.

The National Center of Study Protection and Management of the Caves (CECAV) created a "term of reference" in 2008 (CECAV/IBAMA, 2008) which is the basis for development of management plans aimed at touristic use of caves in the country. This document requires an array of studies in different areas. The main focus is on cave fauna and ecology with little attention paid to microbiological studies. All management plans should include an inventory of pathogenic fungi (especially the species $H$. capsulatum) and their distribution within caves. Baseline data on the presence and distribution of subterranean microbiota is needed to delimit touristic paths in caves and guide monitoring actions.

Vanderwolf and colleagues (2013) bring an interesting review on distribution of fungal species isolated from caves worldwide. As observed in their work there is a gap concerning microbial diversity in Brazilian caves. The authors also highlight the importance of performing studies about fungal distribution, fungal communities and their relation with the environment. We bring in this study a pioneer assay trying to understand the effects of tourism in fungal dispersion as well as testing methods to be used in mycological studies aimed at management plans of show caves.

The general objective of the present study was to perform a more detailed mycological study for the creation of a management plan for a touristic cave in Brazil, and to suggest monitoring actions. This work was requested by government agencies responsible for the monitoring and licensing of cave tourism in Brazil. We aimed to identify the presence of potential pathogenic species, isolate $H$. capsulatum, and detect areas of microbiological risk. We also investigated the effect of touristic activity on air spore-load and air-borne fungi diversity. In the end, we indicate areas of microbiologic risk as a baseline for the creation of a safer touristic route. We also suggest some management actions to minimize the risks of pathogenic fungal outbreaks.

\section{METHODOLOGY}

\section{Study area}

Lapa Nova Cave ("Gruta Lapa Nova") is a $4.55 \mathrm{~km}$ dolomitic cave with two levels and three known entrances. It is located in the municipality of Vazante, Northwestern Minas Gerais state (Brazil), in the environmentally protected area known as APE Lapa Nova (Área de Proteção Estadual Lapa Nova- APE Lapa Nova). This cave is surrounded by areas of urban development, zinc mining, agriculture, and pasture (Auler, 2001).

The environment in Lapa Nova is characterized by an average temperature of $17^{\circ} \mathrm{C}-22^{\circ} \mathrm{C}$ and humidity between $92-100 \%$. Deeper zones of the cave present a constant humidity of $99-100 \%$ and average temperature of $20^{\circ} \mathrm{C}$. Although food resource seems to be scarce in many sites there are many small bat guano patches (fresh and old) distributed along the cave. Lapa Nova is still inhabited by hundreds of bats from at least three species, including hematophagous (Desmodus rotundus and Diphylla ecaudata) and frugivorous (Platyrrhinus sp.) groups. There is a fourth colony, which was not identified due to its location. The cave has many guano patches left by frugivorous, insectivorous and hematophagous bats. Active colonies were mainly observed in a deep area of the cave where there is also a large deposit of mixed bat guano. External vegetal debris is also imported into the cave through two skylights (Fig. 1).

\section{Tourism in Lapa Nova Cave}

Lapa Nova has been visited for at least 140 years (Auler, 2001). Currently, visitation is accessed by the 


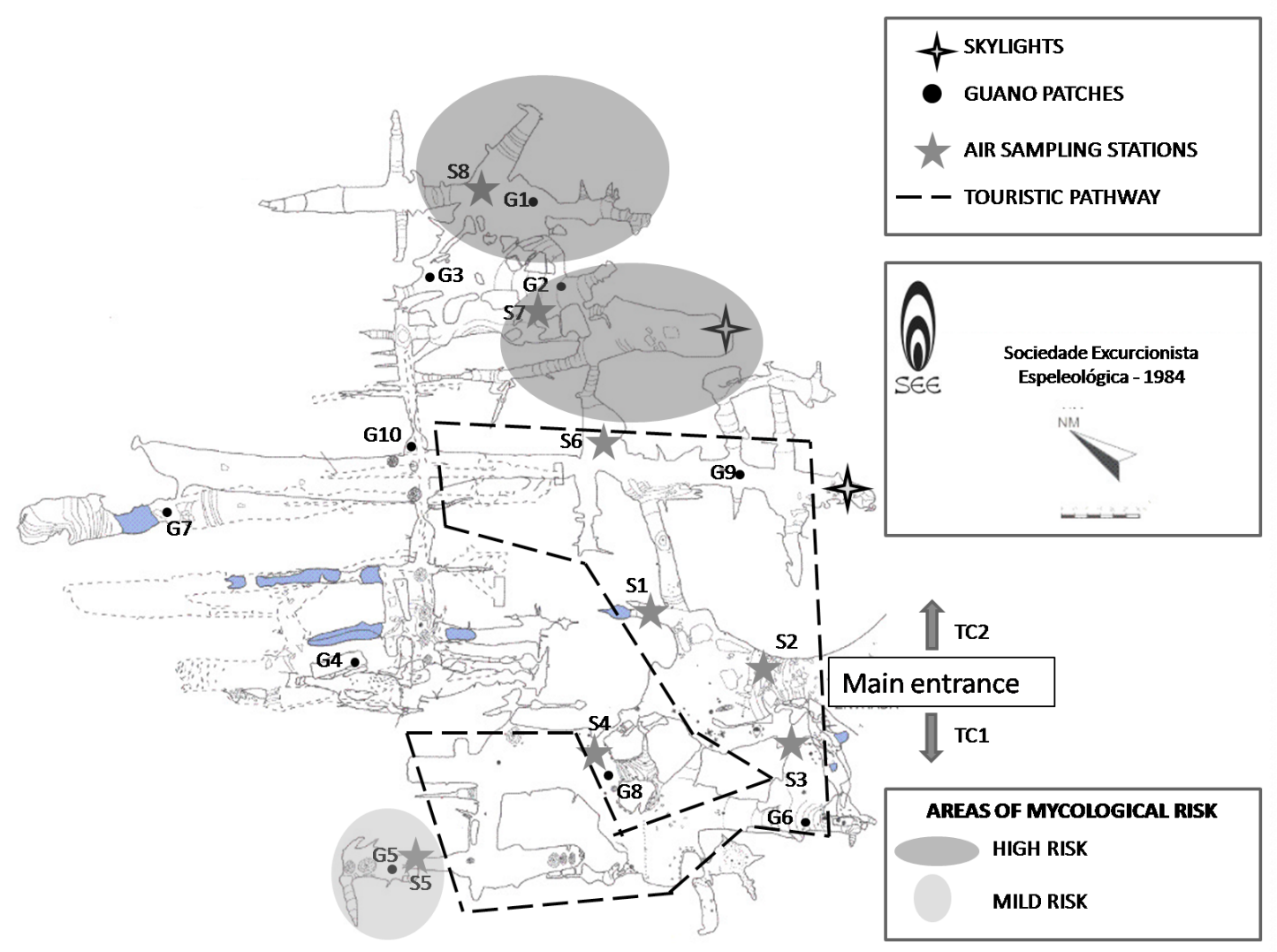

Fig.1. Lapa Nova Cave with touristic pathway (dotted line). Guano (G1-10) and air sampling stations (S1-8) represented by black dots and grey stars respectively. Main (touristic) entrance and main chamber are indicated and skylights highlighted. TC1 indicates main touristic circuit, and TC2, second touristic circuit. Areas classified as mycological risk are also indicated in the map (adapted from Carste, 2009).

main entrance and limited to part of the first level. There are four touristic circuits: the cave entrance, the entrance chamber (accessed by stairs), touristic circuit on the right and touristic circuit on the left side from the entrance chamber (Fig. 1).

Tourism in this cave is mainly represented by a single intense touristic event honoring Virgin Mary. It is known as "Festa da Virgem da Lapa". This event lasts a few days between late April and early May. During this period, the cave is visited by thousands of people drawn mainly by religious beliefs. Throughout the year, visitation in Lapa Nova cave is almost insignificant. The touristic path is quite rudimentary and solely delimited by zebra tapes. A small number of guides are responsible for monitoring visitation.

\section{Sampling stations}

A total of eight sampling stations were selected for the microbiologic inventory and analysis of air sporeload. Four stations were selected in touristic zones (S1, S2, S3 and S6), and the other four in non-touristic zones (S4, S5, S7 and S8). Bat guano samples were also collected to register the presence of any possible pathogenic species and other species of filamentous fungi. Special attention was given to guano presenting visible fungal growth.

The air samples were collected before the intense touristic event (March, 2009) and during the intense touristic event (last day of the religious festival - May, 2009). This procedure aimed to verify the variation on the abundance (total colony forming units - CFU) and richness (number of species) of air-borne fungi between these two periods. The presence of possible pathogenic species was also noted. The number of total visitors was registered during the touristic event in the touristic circuits to compare representativeness of each circuit.

\section{Microbiologic sampling of airborne fungi}

The isolates were obtained through the settle plate technique. Two Petri dishes containing Dichloram Rose Bengal Cloramphenicol Agar (DRBC, Acumedia Laboratories, Lansing, MI USA) and Sabouraud Dextrose Agar (SDA, Difco Laboratories, Detroit, MI USA) with cloramphenicol $(0.1 \%)$ were placed in each sampling station and exposed for twenty minutes. After exposure, they were sealed and incubated at $25^{\circ} \mathrm{C}$ for seven days as standardized for filamentous fungi and considering the cave temperature $\left(17-22^{\circ} \mathrm{C}\right)$. Colony forming units (CFU) were the quantitative parameter considered and used for comparison. The final abundance was determined by the sum of CFUs per sampling station.

Isolates were purified on Malt Extract Agar (MEA, Difco) and incubated at room temperature $\left(25^{\circ} \mathrm{C}\right)$ for at least seven days. The purified colonies were identified to genus and then incubated at specific media for morphological identification (macroscopic and microscopic) of each genus using specific identification keys (Pitt, 2000; Klich, 2002; Samson \& Frisvad, 2004; Domsch et al., 2007). The media used were Neutral Creatine Sucrose Agar $(\mathrm{CNS})^{(1)}$ (according to Samson \& Frisvad, 2004), CYA $^{(2)}$ (Labsynth, Diadema, SP BRAZIL), MEA ${ }^{(3)}$ (Difco) $\mathrm{PDA}^{(4)}$ (Acumedia Laboratories, Lansing, MI USA) and YES $^{(5)}$ (according to Samson and Frisvad, 2004) for the genera Aspergillus (2,3), Calcarisporum ${ }^{(2,3)}$, Cladosporium $^{(3)}$, Chaetomium $^{(2,3)}$ Curvularia ${ }^{(2,3)}$ Emericella ${ }^{(2,3)}$, 
Eurotium (2,3), Fusarium(2,3,4,5), Geotrichum ${ }^{(2,3)}$, Mucor ${ }^{(2,3)}$, Paecilomyces $^{(2,3)}$, Purpureocillium ${ }^{(2,3)}$, Penicillium (1,2,3), Rhizopus $^{(2,3)}$, and Trichoderma ${ }^{(2,3)}(\mathrm{Pitt}, 2000$; Klich, 2002; Samson \& Frisvad, 2004; Domsch et al., 2007). The fungal isolates are currently deposited at the mycological collection at Laboratório de Micologia da Universidade Federal de Minas Gerais (Belo Horizonte, Minas Gerais state - Brazil).

\section{Guano sampling}

A total of two large ( $\geq 25 \mathrm{~m}$ length) and eight smaller ( $\leq 5 \mathrm{~m}$ length) guano patches were sampled in touristic and non-touristic areas (Fig. 1). Each guano deposit presented different characteristics concerning composition (type of guano and other allochtonous material) and time of deposition (according to visual analysis of color, moisture and texture) (Table 1).

One sample of each bat guano of different ages (fresh and old) were collected with sterilized scoops from a delimited area $(15 \mathrm{~cm} \times 10 \mathrm{~cm})$ of the chosen guano patch. These samples were stocked in sterilized vials, sealed in situ and refrigerated at $4^{\circ} \mathrm{C}$ until their processing (not more than 5 days after collection). These samples were processed in laboratory and the isolates were obtained through a 10-fold dilution technique. Guano samples were first diluted in sterilized distilled water $(1: 10)$ and thoroughly mixed for homogenization. This solution was then diluted $\left(10^{-1}\right.$ to $\left.10^{-5}\right)$ in sterilized distilled water with saline solution $(0.85 \% \mathrm{NaCl})$. The solutions were inoculated in triplicates on DRBC and SDA per dilution, totalizing thirty Petri dishes (fifteen containing DRBC and fifteen containing SDA) per guano. After inoculation, the dishes were incubated for seven days at room temperature $\left(25^{\circ} \mathrm{C}\right)$. After incubation, fungal total abundance ( $\mathrm{CFU}$ ) was noted and compared. Colonies were then purified and identified following the method described in the previous topic.

\section{Presence of $H$. capsulatum and other possible pathogenic species}

There has been much research attempting to validate a golden standard for isolation of $H$. capsulatum from

Table 1. Descriptive summary of guano patches in Lapa Nova Cave with fungal abundance represented in total CFU counting.

\begin{tabular}{|l|l|l|l|l|l|}
\hline $\begin{array}{l}\text { Guano } \\
\text { sampling } \\
\text { stations }\end{array}$ & Type & Size* & Age & Touristic status & CFU \\
\hline G1*** & M (F and H) & Large & Old $(\mathrm{H}) /$ fresh $(\mathrm{H}, \mathrm{F})$ & Non-touristic & 915 \\
\hline G2 & $\begin{array}{l}\text { M }(\mathrm{F} \text { and H) } \\
\text { VD }\end{array}$ & Large & Old & Non-touristic & 101 \\
\hline G3 & H & Small & Old & Non-touristic & 155 \\
\hline G4 & H & Small & Old & Non-touristic & 23 \\
\hline G5 & M (H, I) & Small & Old & Non-touristic & 305 \\
\hline G6 & H & Small & Fresh & Touristic & 39 \\
\hline G7 & H & Small & Old & Non-touristic & 79 \\
\hline G8 & I & Small & Old & Touristic & 257 \\
\hline G9 & H & Small & Old & Touristic & 22 \\
\hline G10 & H & Small & Old & Touristic & 152 \\
\hline
\end{tabular}

(F) frugivorous; $(\mathrm{H})$ hematophagous; (I) insectivorous; and (M) mixed guano.

${ }^{*}$ large $\geq 25 \mathrm{~m} /$ small $\leq 5 \mathrm{~m}$.

** (VD) deposition of vegetal debris aside the guano, proximity to entrance

${ }^{* * *}$ site with active bat colony the environment (Guimarães et al., 2006; Léon et al., 2012). We attempted to isolate $H$. capsulatum from air and guano using three different methods: 1) direct plating of suspicious material, 2$)$ serial dilution $\left(10^{-1}\right.$ $\left.-10^{-5}\right)$ in distilled water enriched with peptone $(0.1 \%)$ (triplicates were performed for each sample), and 3) settle plate method (20 minutes).

The media used were $\operatorname{SDA}\left(25^{\circ} \mathrm{C}\right)$ and Brain Heart Infusion Agar (BHIA, Acumedia) $\left(37^{\circ} \mathrm{C}\right)$ (CarvajalZamora, 1977; Gompertz et al., 2004; Guimarães et al., 2006) with chloramphenicol (1\%) to inhibit bacteriological growth. All dishes were observed from five to forty-two days after inoculation. Daily observations were performed in the first 21 days and three times a week afterwards.

The conversions of the yeast form into the mycelial form into yeast form were also performed to help in the identification of the species (Carvajal-Zamora, 1977; Gompertz et al., 2004; Guimarães et al., 2006). Slides of the suspicious material were prepared to observe the microscopic characteristics of both mycelia and yeast forms.

Concerning other possible pathogenic species, the first pathogenic feature considered for triage was growth at $37^{\circ} \mathrm{C}$ on SDA and BHIA. All colonies growing at this temperature were identified and compared to known medical cases of opportunistic human fungal infections. These species were then classified as potentially pathogenic species and locations with large concentrations were considered areas of risk and marked for microbiological monitoring. We categorized an area as 'large concentration' when the possible pathogenic species represented more than $30 \%$ of the total CFU isolated from the sampling station.

\section{Statistical analysis}

The non-parametric Kruskal-Wallis test was used to verify the visitation effect on the abundance and richness of air-borne fungi per sampling station. For that we compared results obtained before the touristic event with those obtained on the last day of the festival (touristic event). To standardize sampling effort, we placed the Petri dishes (duplicate) in the exact same place during both events. The media, Petri dish size and time of exposure were also standard in both sampling periods. The program Statistica 9.0 was used for statistical analysis.

\section{RESULTS}

\section{Abundance, richness and diversity of filamentous fungi}

A total of 2,575 filamentous fungi were isolated from the guano $(1,739)$ and from the air $(836)$. These isolates included 47 species distributed among 15 genera (Table 2).

Sampled air-borne fungi were composed of 25 species and 10 genera: Aspergillus (33.3\%), Penicillium (29.1\%), Cladosporium (8.3\%), Fusarium (8.3\%), Calcarisporum (4.1\%), Chaetomium (4.1\%), Curvularia (4.1\%), Emericella (4.1\%), Geotrichum (4.1\%), and Trichoderma (4.1\%). The most diverse genera were Aspergillus and Penicillium with eight 
and seven of the total species isolated from the air respectively. The highest abundance (86 CFU) registered among the air samples, was registered in the sampling station S3, during the religious festival (Fig. 2).The highest richness registered from the air samplings before the Festival was obtained in S2 and S8 $(S=10)$. However, the highest richness registered during the Festival was obtained in S3 $(S=16)$. The results for the other sampling stations may be observed in Figs. 2 and 3.

\section{$\rightarrow-$ before visitation during visitation}

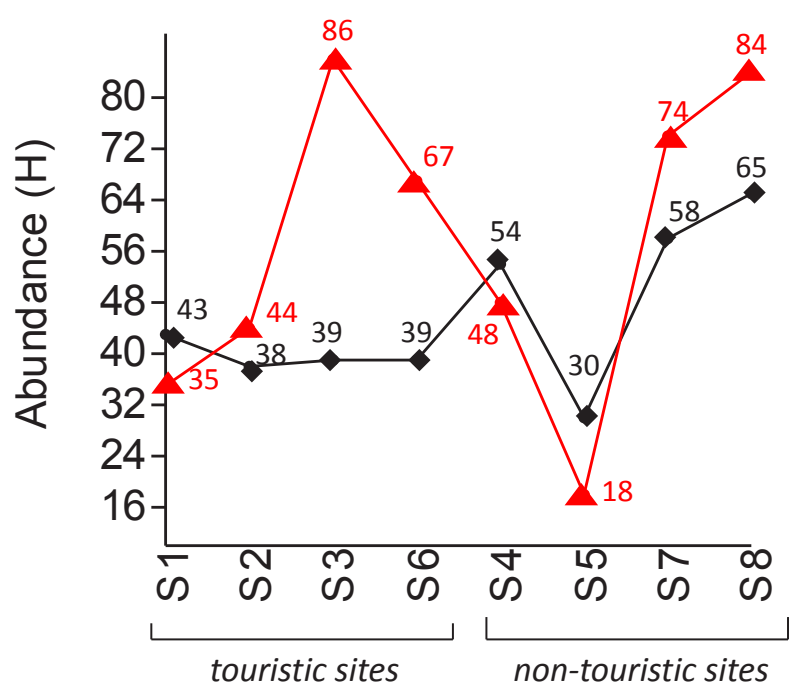

Fig. 2. Variation on abundance $(\mathrm{H})$ of air-borne filamentous fungi in touristic and non-touristic sites along the sampling stations (S1-8). Abundance is represented by total CFU and compared before (black rhombus) and during (red triangle) intense visitation in Lapa Nova Cave.
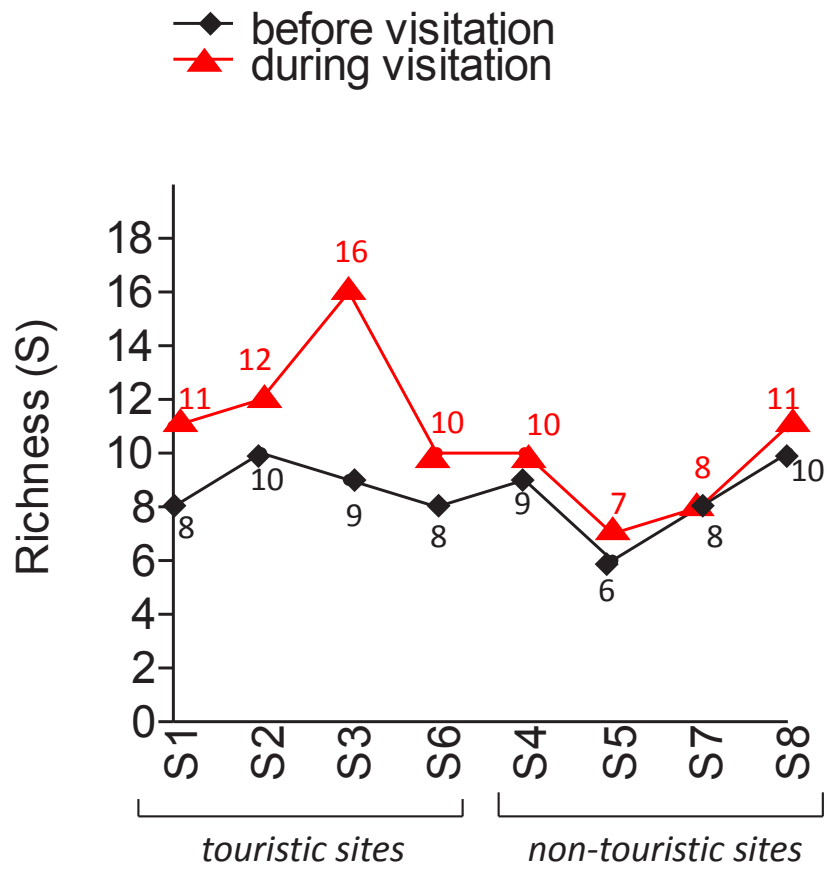

Fig. 3. Variation of richness $(\mathrm{H})$ of air-borne filamentous fungi in touristic and non-touristic sites along the sampling stations (S1-8). Richness is represented by number of species and compared before (black rhombus) and during (red triangle) intense visitation in Lapa Nova Cave. Richness increase observed in most sampling sites due to cave visitation.
A total of 2,039 CFUs were counted from the guano samples including yeasts (300) and filamentous fungi $(1,739)$. The guano patch with the highest counting was G1, which is a fresh mixed large guano deposit (Table 1). Fungi isolated from guano was represented by at least 43 species of 12 genera of filamentous fungi: Aspergillus (34.8\%), Penicillium (34.8\%), Cladosporium (8.3\%), Eurotium (4.6\%), Fusarium (4.6\%), Mucor (4.6\%), Emericella (2.3\%), Gliocladium (2.3\%), Paecilomyces (2.3\%), Purpureocillium (2.3\%), Rhizopus (2.3\%) and Trichoderma (2.3\%). Once more, the most diverse genera were Aspergillus and Penicillium, with 15 species each. They were also the most abundant with 806 and 359 isolates respectively. The genera Trichoderma and Purpureocillium also presented a high number of isolates (259 and 226 respectively).

The highest abundance (914 CFU) of filamentous fungi isolated from guano was obtained in the sampling station G1, followed by G5 (305 CFU) and G8 (257 CFU) (Table 1).

\section{Potential pathogenic and allergenic species}

Histoplasma capsulatum was not isolated from Lapa Nova cave. However, various isolates from eleven species were considered possible pathogenic species: Aspergillus flavus, Aspergillus japonicus, Aspergillus niger, Aspergillus versicolor, Aspergillus ustus, Fusarium oxysporum, Fusarium solani, Mucor sp., Purpureocillium lilacinum, Rhizopus sp. and Thricoderma viride. These species presented positive growth at $37^{\circ} \mathrm{C}$ and have already been associated with various opportunistic fungal infections in humans (Lacaz et al., 2002). Cladosporium cladosporioides is known for producing serious toxins and for being a strong allergenic species (Tasic \& Tasic, 2007). Since some isolates of $C$. cladosporioides were also able to grow at $37^{\circ} \mathrm{C}$ and due to its allergenic potential, it was included in this list.

The species considered of medical importance were distributed along the cave in touristic and nontouristic stations (Table 3). However, the species A. niger, Mucor spp, P. lilacinum and Rhizopus sp. were solely isolated from guano samples.

The occurrence of the possible pathogenic species isolated from the air varied before and during touristic visitation in some stations, as shown in Table 3. However, Aspergillus flavus, C. cladosporioides, F. solani, $F$. oxysporium and $T$. viride were constant in other areas (especially in S8). This last air sampling station was located close to the large guano patch. Fusarium solani was isolated from almost all air sampling stations. In most cases it presented low frequency $(<10 \%)$. However, its frequency was high in S5 (27\%), S8 (29.6\%) and S7 (26.8\%) as well as highly isolated from G1 and G2.

Three areas were considered of microbiologic risk since they had high concentration of possible pathogenic fungi (Fig. 1). Two of these areas were classified as highly risky due to elevated levels of airborne fungi, high frequency of possible pathogenic species, and presence of active bat colonies producing large guano patches. The other area was considered of mild risk since its only 
Table 2. Fungi isolated from air and guano in Lapa Nova Cave and reference* of their occurrence in other caves indicating worldwide distribution in subterranean ecosystems.

\begin{tabular}{|c|c|c|}
\hline Taxa & $\begin{array}{l}\text { Distribution } \\
\text { in Lapa } \\
\text { Nova }\end{array}$ & $\begin{array}{l}\text { Other cave } \\
\text { occurrence }\left(^{*}\right)\end{array}$ \\
\hline \multicolumn{3}{|l|}{ Ascomycota: } \\
\hline Aspergillus caespitosus Raper \& Thom 1944 & $A, G$ & 9 \\
\hline A. candidus Link 1809 & $A, G$ & 7 \\
\hline A. clavatus Desmàzieres 1834 & G & 7 \\
\hline A. flavus Link 1809 & $A, G$ & $1,3,4,6,7$ \\
\hline A. japonicus Saito 1906 & $A, G$ & 9 \\
\hline A. niger Tieghem 1867 & G & $1,2,34,6,7,9$ \\
\hline A. niveus Blochwitz 1929 & G & 9 \\
\hline A. ochraceus Wilhelm 1877 & $A, G$ & 3,9 \\
\hline A. restrictus Smith 1931 & G & 9 \\
\hline A. sclerotiorum Hubber 1933 & G & 9 \\
\hline A. sydowii (Bainier \& Sartory) Thom \& Church 1926 & $A, G$ & 9 \\
\hline A. ustus (Bainier) Thom \& Church 1926 & $A, G$ & 7,9 \\
\hline A. versicolor (Vuillemin) Tiraboschi 1908 & $A, G$ & $5,7,9$ \\
\hline A. wentii Wehmer 1896 & G & 3,9 \\
\hline Aspergillus sp. & G & - \\
\hline Calcarisporium sp. & A & - \\
\hline Chaetomium sp. & A & - \\
\hline Cladosporium cladosporioides (Fresenius) Vries 1952 & $A, G$ & $1,4,6,7,9$ \\
\hline C. herbarum (Persoon) Link 1816 & $A, G$ & $1,4,7,9$ \\
\hline Curvularia sp. & A & - \\
\hline Emericella rugulosa (Thom \& Raper) Benjamin 1955 & $A, G$ & 9 \\
\hline Eurotium amstelodani Mangin 1909 & G & 9 \\
\hline Fusarium oxysporum Schlechtendal 1824 & $A, G$ & $1,4,6,9$ \\
\hline F. solani (Martius) Saccardo 1881 & $A, G$ & $4,7,8,9$ \\
\hline Geotrichum sp & A & - \\
\hline Gliocladium roseum Bainier 1907 & G & $1,4,9$ \\
\hline $\begin{array}{l}\text { Purpureocillium lilacinum (Thom) Luangsa-ard, } \\
\text { Houbraken, Hywel-Jones \& Samson } 2011\end{array}$ & G & $1,6,7,9$ \\
\hline Paecilomyces variotii Bainier 1907 & G & 7,9 \\
\hline P. brevicompactum Dierckx 1901 & $A, G$ & 9 \\
\hline P. chrysogenum Thom 1910 & $A, G$ & $1,4,6,7,9$ \\
\hline P. citrinum Thom 1910 & $A, G$ & 7,9 \\
\hline P. decumbens Thom 1910 & G & 7,9 \\
\hline P. expansum Link 1809 & $A, G$ & 7,9 \\
\hline P. glabrum (Wehmer) Westling 1911 & A & 7,9 \\
\hline P. griseofulvum Dierckx 1901 & $A, G$ & 9 \\
\hline P. islandicum Sopp 1904 & G & - \\
\hline P. oxalicum Currie \& Thom 1915 & G & 9 \\
\hline P. pinophilum Hedgcock 1910 & G & 9 \\
\hline P. purpurogenum Stoll 1904 & G & 7,9 \\
\hline P. simplicissimum (Oudemans) Thom 1930 & A & 9 \\
\hline P. solitum Westling 1911 & G & 7 \\
\hline P. thomii Maire 1917 & G & 7,9 \\
\hline P. variabile Sopp 1912 & $A, G$ & $1,4,7,9$ \\
\hline Trichoderma viride Persoon 1794 & $A, G$ & 9 \\
\hline \multicolumn{3}{|l|}{ Zygomycota: } \\
\hline Mucor sp.1 & G & - \\
\hline Mucor sp.2 & G & - \\
\hline Rhizopus sp. & G & - \\
\hline
\end{tabular}

$A=$ isolated from air; $G=$ isolated from guano;

*Only species citation was considered;

(1) Carvajal-Zamora \& Nieves Rivera, 1998; (2) Nieves-Rivera \&

Carvajal-Zamora, 2000; (3)Koilraj et al, 2000; (4) Nieves-Rivera, 2003;

(5) Ulloa et al, 2006; (6) Nieves-Rivera et al., 2009, (7) Nováková,

2009; (8) Resende-Stoianoff et al., 2012; (9) Vanderwolf et al., 2013.
Table 3. Distribution of potential pathogenic species (filamentous fungi) isolated from the air before (B) and during (D) the touristic event along the air sampling stations (S).

\begin{tabular}{|c|c|c|c|c|c|c|c|c|c|}
\hline Stations & $A f$ & $A j$ & $A v$ & $A u$ & $c c$ & Ch & Fo & Fs & $T$ \\
\hline $\mathrm{S} 1 \mathrm{~B}^{*}$ & 0 & 0 & 0 & 0 & 0 & 0 & 0 & + & 0 \\
\hline S1 $D^{*}$ & 0 & 0 & 0 & 0 & 0 & + & 0 & + & 0 \\
\hline S2 $\mathrm{B}^{*}$ & 0 & + & + & 0 & + & 0 & 0 & + & + \\
\hline S2 $D^{*}$ & 0 & + & + & 0 & + & + & 0 & + & + \\
\hline S3 $B^{*}$ & 0 & + & 0 & + & 0 & 0 & 0 & + & 0 \\
\hline S3 $D^{*}$ & 0 & + & 0 & + & + & + & 0 & + & 0 \\
\hline S4 B & 0 & 0 & 0 & 0 & + & + & + & + & 0 \\
\hline S4 D & 0 & 0 & 0 & 0 & + & + & + & + & 0 \\
\hline S5 B & 0 & 0 & 0 & 0 & 0 & 0 & 0 & 0 & 0 \\
\hline S5 D & 0 & 0 & 0 & 0 & 0 & 0 & + & + & 0 \\
\hline$S 6 B^{*}$ & 0 & 0 & 0 & 0 & + & + & 0 & 0 & 0 \\
\hline$S 6 D^{*}$ & 0 & 0 & 0 & 0 & + & + & 0 & + & 0 \\
\hline S7 B & 0 & 0 & 0 & 0 & 0 & + & 0 & + & + \\
\hline S7 D & 0 & + & 0 & 0 & + & + & 0 & + & + \\
\hline S8 B & + & + & 0 & 0 & + & 0 & + & + & + \\
\hline S8 D & + & + & 0 & 0 & + & + & + & + & + \\
\hline
\end{tabular}

$S(1-8)=$ sampling stations; ${ }^{*}=$ touristic pathway sampling stations; 0 = absent; + = present. Fungi species represented by: (Af)

Aspergillus flavus, (Aj) Aspergillus japonicus, (Au) Aspergillus ustus, (Av) Aspergillus versicolor, (Cc) Cladosporium cladosporioides, (Ch) Cladosporium herbarum, (Fo) Fusarium oxysporum, (Fs) Fusarium solani, and (T) Trichoderma viride.

feature was presence of high frequency of $F$. solani and moderate to high airborne spore-load.

\section{Variation of conidial air dispersion during touristic activity}

Data provided by Carste (2009) showed that a total of 3,202 tourists visited the cave entrance chamber during the religious festival in 2009. From this total, 1,438 tourists visited the touristic circuit $\mathrm{TC} 1$ and 1,023 tourists visited the touristic circuit TC2.

From the 836 airborne isolates obtained in both sampling events, 366 (43.77\%) were obtained before the religious festival and 470 (56.23\%) during the event. The abundance (CFU) of air-borne filamentous fungi increased from before and during intense visitation in $62.5 \%$ at sampling stations (S2, S3, S6, $\mathrm{S} 7$, and $\mathrm{S} 8$ ) and decreased in $37.5 \%$ (S1, S4 and S5) (Fig. 2). However, no statistically significant relation was observed.

Concerning richness of air-borne filamentous fungi, a statistically significant increase occurred in almost all stations (except for S7) during the intense touristic activity (Fig. 3). The Kruskall-Wallis analysis showed a statistically significant $(p<0.05)$ relation between the richness of air-borne filamentous fungi and the intense touristic activity in touristic sampling stations along Lapa Nova Cave. However, this relation was not significant $(p>0.05)$ for the sampling stations located in non-touristic areas (Fig. 4).

\section{DISCUSSION}

\section{Fungal assemblages in Lapa Nova cave}

Lapa Nova Cave holds a variety of types of guano with different times of deposition. This provides a mosaic of microhabitats for fungal colonization and 


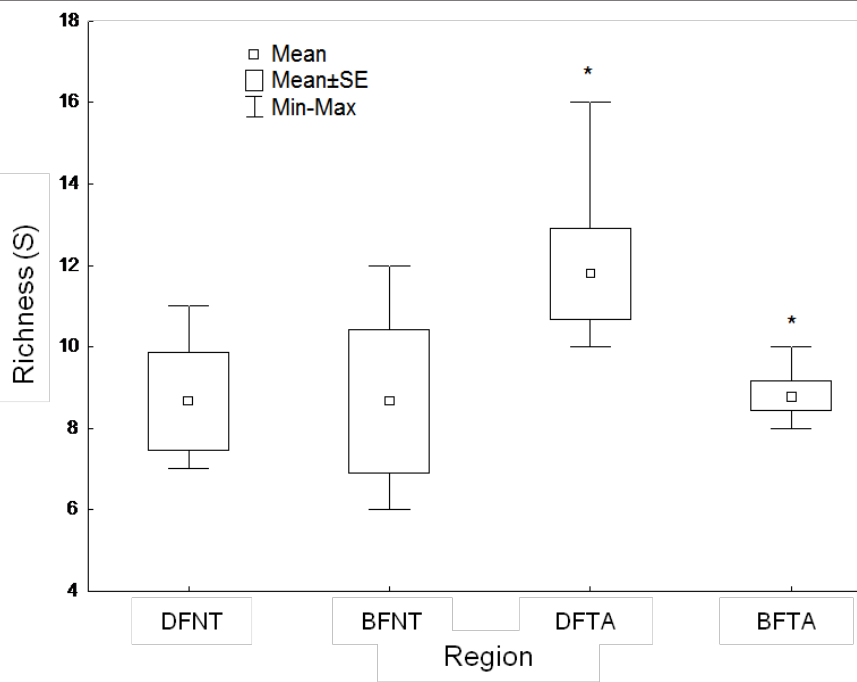

Fig. 4. Kruskal-Wallis Test comparing the relation between richness of air borne fungi and cave visitation. Samples displayed in boxplots considering touristic and non-touristic areas during and before visitation: richness during festival in non-touristic areas (DFNT), before festival in non-touristic areas (BFNT), during festival in touristic areas (DFTA), and before festival in touristic areas $(B F T A)$. Significant $(p<0.05)$ statistical relation observed in touristic areas is represented with $\left({ }^{*}\right)$, indicating relation between cave visitation and dispersion of air-borne fungi (increasing richness). Means, maximum and minimum values observed per group are also represented (boxplot).

growth. Nieves-Rivera et al. (2009) discussed that fresh guano (rich in nutrient) combined with the stable environmental conditions of cave systems may provide excellent conditions for fungal growth. Ferreira and colleagues (2000) have already registered significant fungal diversity associated with bat guano in a cave in Brazil.

The high fungal abundance observed in the largest guano patch (G1) could be related to time of exposure and heterogeneous composition. It is widely known that more heterogeneous habitats may provide more diverse communities (Ricklefs \& Schluter, 1993; McClain \& Barry, 2010). Difference of guano age (old and fresh) and type (frugivorous, hematophagous, and insectivorous) observed in this site could be providing a more heterogeneous habitat for fungal growth, promoting high abundance. In addition, the active bat colony may also be contributing with constant import of microorganisms and organic matter.

Previous studies have already shown that touristic activities influence microbial distribution in a cave (Barton \& Northup, 2007; Wang et al., 2010, Shapiro \& Pringle, 2010; Fernández-Cortés et al., 2011). This relation could easily be associated with conidial suspension, microbial import and environmental changes caused by visitation (Vanderwolf et al., 2013). Fernández-Cortés and colleagues (2011) monitored fungal and bacterial variations associated with touristic activity and found that fungal dispersion inside the cave was related with opening of the entrance door. This does not seem to be occurring in Lapa Nova, as there are no doors controlling tourist entrance. It is possible that visitation is influencing spore suspension and causing variations on fungal dispersion and species occurrence. The significant relation between visitation and fungal richness observed in touristic areas sustains this hypothesis and points to possible enrichment of these areas through fungal import by tourists, as previously discussed by Barton \& Northup (2007). Visitation may also cause conidial transfer from different sites in the cave or even allochtonous import from the epigean system.

Shapiro \& Pringle (2010) observed that fungal diversity decreased in highly trafficked sites. Contrary to their findings, we observed that the straightest passage with higher human traffic (S3) presented the highest variation on spore-load and fungal richness during visitation. However, this data was not sufficient to provide with statistically significant results. Finally, after analyzing the data obtained in this study, it is plausible to state that fungal dispersion in Lapa Nova cave is influenced by tourism in visited areas, since a significant relation between visitation and fungal richness was only observed in touristic sites.

Aspergillus and Penicillium were the most common genera isolated from Lapa Nova Cave. This result is in accordance with data presented by Vanderwolf and colleagues (2013) in their review on fungal communities in caves worldwide. Both genera are the most commonly isolated from many different environments (Pitt, 2000; Klich, 2002). Similar results have been observed in other caves in Brazil (Casirillión et al., 1976) and worldwide (Koilraj et al., 1999; Nieves-Rivera, 2003; Ulloa et al., 2006; Nieves-Rivera et al., 2009; Novaková, 2009; Vanderwolf et al., 2013), showing that these are the most common filamentous fungi isolated from subterranean environments.

Comparisons with other studies on cave mycobiota in Brazil are difficult since studies on cave microbiota are scarce and focus on different topics (consequently using different media and methods). The few published studies mainly focus on identification of Basidiomycets (Pedro \& Bononi, 2007), isolation of dermatophytes (Casirillión et al., 1976; Silveira, 1985), fungal response to antifungal drugs (Resende-Stoianoff et al., 2012) and fungi association with other invertebrates (McCarthy et al., 2011). However, some similarities have been observed, such as that Fusarium solani has already been isolated from guano in a Brazilian cave (ResendeStoianoff et al., 2012) and the fact that Aspergillus and Penicillium have been isolated in the same proportion by Casirillión and colleagues (1976). These similarities and the lack of studies highlight the importance of performing more studies on cave fungi in the country for further comparison.

Concerning pathogenic species, $H$. capsulatum was not isolated from Lapa Nova cave. This may represent its true absence or the result of a low spore concentration in the environment. It may also be related with the efficiency of current isolation methods (CarvajalZamora, 1977; Guimarães et al., 2006; Léon et al., 2012). Léon and colleagues make a comparison and discuss about the efficiency of $H$. capsulatum isolation methods (direct isolation, molecular identification and mice inoculation) indicating possible deficiencies in diagnosis. Thus, epidemiological studies are also supposed to be considered when working with the microbiological risks during management plan of show caves. It is important to highlight that although 
histoplasmosis has already been recorded in Brazil (Capone et al., 1999; Unis et al., 2005; Guimarães et al., 2006), with cases related with cave visitation (Cury et al., 2001) or contact with bat guano (Oliveira et al., 2006), there are no records of histoplasmosis associated with the study cave or region.

The guano patches G1 and G2 should be classified as high risk sites, since they feature conditions favorable for sudden fungal outbreaks. Their trophic status, fungal abundance, presence of possible pathogenic species, risk of introduction of new species by active bat colony (G1) and cave entrance (G2) are factors that enhance the risk of a sudden fungal outbreak.

Lapa Nova cave harbors opportunistic fungal pathogens from the genera Aspergillus, Cladosporium, Mucor, Rhizopus, Purpureocillium and Fusarium Boutati and Anaissie (1997) reported many medical cases of opportunistic infections caused by Fusarium spp. in immunocompromised patients. Nucci \& Anaissie (2002) presented medical cases relating Fusarium to cutaneous infection in both immunocompromised and healthy patients. However no studies have been conducted associating opportunistic infections with cave visitation in Brazil. The scarce existing studies generally focus on histoplasmosis associated with cave visiting (Cury et al., 2001) and isolation of dermatophytes (Casirillión et al., 1976; Silveira, 1985).

We have collected $A$. flavus (an important infective agent causing pulmonary aspergillosis in immunocompromised patients), $F$. solani and $F$. oxysporum from the air and the soil in many of the studied sites (Table 3). These species were most frequent in the two large guano piles (G1 and G2), which could be a reason to classify these sites as dangerous for touristic use.

Other species isolated during this study are known to be associated with opportunistic fungal infections, such as onycomycosis (A. versicolor, A. ustus, $F$. solani, and $F$. oxysporum) (Veraldi et al., 2010), human otitis (A. flavus, A. japonicus) (Agudo et al., 2011), cutaneous mycosis (P. lilacinum) (Takayasu et al., 1977), pulmonary aspergillosis (A. flavus) (Kousha et al., 2011) and other opportunistic fungal infections ( $F$. solani and F. oxysporum) (Nucci \& Anaissie, 2002). We have also isolated well known allergenic species (C. cladosporioides and C. herbarum) (Zhang et al., 1996; Chou et al., 2008). Although they are not considered fungal pathogens, both species produce extremely allergenic compounds and could cause respiratory problems to cave visitors (Zhang et al., 1996). Interestingly, these species were added to three of the four touristic airborne sampling stations during visitation. Since these fungi are common indoors mold found in human households, their dispersion in these sites could be human related or merely dispersion between cave sites due to human visitation. Furthermore, we have also observed that other opportunistic species (Fusarium oxysporum and $F$. solani) were more frequently isolated from the air and more distributed among the sites during visitation. These species are ubiquitous (commonly isolated from air, soil, plants and animals) and commonly found associated with humans. This could be another evidence of fungal dispersion or import due to human visitation.
The possible pathogenic (A. flavus, A. japonicus, A. ustus, A. versicolor, F. oxysporum, F. solani and Trichoderma sp.) and allergenic (C. cladosposrioides and $C$. herbarum) species have already been registered in touristic and non-touristic caves in other countries (Koilraj et al., 1999; Hsu \& Agoramoorthy, 2001; Nieves-Rivera, 2003; Nieves-Rivera et al., 2009; Novaková, 2009, Vanderwolf et al., 2013). Although these potential pathogenic species were isolated in Lapa Nova Cave, they are commonly found in external environments. However, caves are enclosed systems with environmental conditions that could favor fungal growth. Thus, the spore levels of these species in the air should be constantly monitored to minimize the exposure of tourists to heavy microbial loads in the air.

Finally, monitoring (air, sediment and guano) should be a common practice in all show caves in order to detect sudden fungal outbreaks, such as the histoplasmosis outbreak registered by Lyon and colleagues in a show cave in Costa Rica (2004).

\section{Final considerations for the touristic use of Lapa Nova Cave}

The large bat guano deposits (G1 and G2) presented large visible colonies of Fusarium and Aspergillus, which could pose risks to cave visitors. The soil in these areas is very dry and easily suspended by stepping. Therefore, visitation to these areas should be prohibited. Furthermore, considering the presence of active bat colonies we suggest microbiota in Lapa Nova cave, movements and formation of new bat colonies and spore levels in the air should be monitored.

The large number of show caves in the country, the lack of information on microbial communities, presence of pathogenic and opportunistic species and absence of a microbiological monitoring protocol for management plans in show caves are alarming. We agree with Vanderwolf et al. (2013) on the importance of performing more studies on microbial communities in subterranean environments, particularly their interactions and relation with touristic activities. We considered the lack of basic information among tourists and the possible risks posed by visiting show caves and selected the following actions as highly commendable.

All visitors should be advised about: 1) the microbiologic risks, 2) avoiding contact with contaminated substrates (e.g., cave floor, walls, water, vegetal debris, guano and speleothems), 3) wear proper clothing covering exposed body parts which could be in contact with contaminated substrate (e.g., feet and legs), 4) avoid eating or drinking in the cave, and 5) not to litter (to avoid the introduction of organic matter that may serve as substrate for the development of cave microorganisms). This information could be provided through flyers, a visitors center with introductory presentation or even guidance by trained monitors.

More specifically, investigation of presence of $H$. capsulatum and other possible pathogenic species should be performed at least once every trimester (since it is a slow growing species), and especially before this intense touristic event ("Festa da Virgem da Lapa"). Guides must be advised about the symptoms and risks of histoplasmosis and medical check-ups 
should be periodically provided by the managers responsible for the show cave.

Any material introduced into the system, either for structural or maintenance reasons should first be evaluated and sterilized to avoid introduction of new microorganisms or organic matter for the development of fungal colonies. Thus, the risk of any fungal outbreak may be diminished and the trophic pristine conditions preserved. Since the soil is extremely compacted in touristic areas, it does not seem urgent the construction of pathways. However, this could be confirmed with long-term microbiologic monitoring.

\section{CONCLUSION}

The present study showed that caves hold an array of filamentous fungi which also include some possible opportunistic species. The distribution of cave mycobiota of Lapa Nova Cave is a dynamic process that should be considered when using these systems for touristic purposes. The impacts that touristic activities may have on fungi and the risk these microorganisms may pose to the visitors show the importance of constantly advising tourists and guides. The dynamic distribution of fungi along a cave shows the importance of a periodic microbial monitoring, especially in bat inhabited touristic caves.

Microbial communities are present in different substrates, especially on organic matter deposits. Therefore, it is important to assess the microbial composition of a cave before starting touristic activities and introducing structures which may serve as food resources and possible development of pathogenic organisms. Microbiologic studies of air, soil and other substrates should be performed before establishing a touristic route and building touristic structures. Efforts should be made to agree with the many areas involved in a management plan and approve building structures that will diminish the risk of soil disturbance and consequent aerosols and conidial dispersion, also aiming for a minimum impact.

More studies on methods and the development of a standard protocol to be used in management plans for show caves should be conducted. Future management plans should include more detailed microbiological studies, including more sampling events, to better understand relationships between cave microbiota and the environment. It is also clear that different methods should be used in the microbiologic studies. For future studies, molecular and soil washing methods should be included for a better result. More studies concerning isolation of $H$. capsulatum should also be encouraged. Local governmental representatives should invest in training and informing local health agents (e.g., health caretakers) in order to aid in the diagnosis and epidemiologic reports of more serious fungal infections that might be related with cave visitation, such as histoplasmosis.

\section{ACKNOWLEDGEMENTS}

Part of the information contained in this study aided in the creation of the management plan of Lapa
Nova cave, which was the first plan containing a more detailed microbiologic study to be approved by CECAV/IBAMA (National Center of Study Protection and Management of the Caves) in Brazil. The authors are thankful to the companies CAPES, VOTARANTIM and CARSTE CONSULTORES for the financial support; the cave guides Severino and Rivaldo for help in the field and information provided; Edson Luís Resende and Professor Ludwig H. Pfenning from Laboratório de Sistemática e Ecologia de Fungos da UFLA (Laboratory of Fungal Systematics and Ecology at the Federal University of Lavras - UFLA), Dr. Daiani Silva, Msc. Fabiana Passamani, Professor Luis Roberto Batista and all the friends from NETAX (Aspergillus and Penicillium Taxonomic Nucleous) for the help on the identification of the isolates; and Professors Lucas Del Bianco Faria and Patricia Gomes for all the suggestions in the manuscript.

\section{REFERENCES}

Agudo L.G., Aznar-Marín P., Galán-Sánchez F., GarcíaMartos P., Marín-Casanova P. \& Rodriguez-Iglesias M., 2011 - Onycomycosis due to filamentous fungi. Mycopathologia, 172: 307-310. http://dx.doi.org/10.1007/s11046-011-9427-5

Armstrong D., 1993 - Treatment of Opportunistic Fungal Infections. Clinical Infectious. Diseases, 16 (1):1-7.

Ashford D.A., Hajjeh R.A., Kelley M.F., Kaufman L. \& McNeil A., 1999 - Outbreak of histoplasmosis among cavers attending the National Speleological Society Annual Convention, Texas, 1994. American Journal of Tropical Medicine and Hygiene, 60: 899-903.

Auler A.S., Rubbioli E. \& Brandi R., 2001 - As grandes cavernas do Brasil. Grupo Bambuí de Pesquisas Espelológicas, Belo Horizonte, 277 p.

Barton H.A., 2006 - Introduction to cave microbiology: a review for the non-specialist. Journal of Cave and Karst Studies, 68 (2): 43-54.

Barton H.A. \& Northup D.E., 2007 - Geomicrobiology in cave environments: past, current and future perspectives. Journal of Cave and Karst Studies, 69 (1): 163-178.

Boggiani P.C., Silva O.J., Gesicki A.L.D., Gallati E.A.B., Salles L.O. \& Lima M.M.E.R., 2008 - Definição de capacidade de carga turística das cavernas do Monumento Natural Gruta do Lago Azul (Bonito, MS). Geociências, 26 (4): 333-348.

Boutati E.I. \& Anaissie E.J., 1997 - Fusarium, a significant emerging pathogen in patients with hematologic malignancy: ten years' experience at a cancer center and implications for management. Blood, 90: 999-1008.

Capone D., Wanke B., Monteiro P.C., Lazéra M.S., Andrade G.N. \& Do Valle A.C. 1999 - Chronic pulmonary histoplasmosis in the state of Rio de Janeiro, Brazil. Mycopathologia, 145 (2): 75-9.

http://dx.doi.org/10.1023/A:1007016414833

Carste C.A. 2009 - Plano de manejo espeleológico de Lapa Nova, Vazante, Minas Gerais. Votarantim Metais, Belo Horizonte, $118 \mathrm{p}$.

Carvajal-Zamora J.R., 1977 - Isolation of Histoplasma capsulatum from soil in Aguas Buenas caves, Aguas Buenas, Puerto Rico. Mycopathologia, 60 (3): 157-161. Carvajal-Zamora J.R. \& Nieves-Rivera A., 1998 Preliminary checklist of cave mycobiota of Puerto Rico with special reference to bat guano enriched soil hyphomycetes. Inoculum, 49: 1 .

http://dx.doi.org/10.1007/BF00448408 
Casirillión A.L., Moraes M.A.P. \& Furtado M.S.S., 1976. Isolamento de Microsporum amazonicum do solo do estado do Amazonas, Brasil. Acta Amazônica, 6 (4):487-90.

CECAV/IBAMA, 2009 - Instruções normativas para elaboração de estudos espeleológicos. http://www.icmbio.gov.br/cecav/images/download/ IN\%2002 MMA Comentada.pdf

Chou H., Tam M.F., Lee L., Chiang C., Tai H., Panzani R.C., 2008 - Vacuolar serine protease is a major allergen of Cladosporium cladosporioides. International Archives of Allergy and Immunology, 146: 277-286. http://dx.doi.org/10.1159/000121462

Culver D.C., 1982 - Cave Life, Evolution and Ecology. Cambridge, Massachussets and London, England: Harvard University Press. 189 p.

Cury G.C., Filho A.D., Cruz A.G.C. \& Hobaika A.B.S., 2001 - Surto de histoplasmose em Pedro Leopoldo, Minas Gerais, Brasil. Revista Sociedade Brasileira de Medicina Tropical, 34 (5): 483-486. http://dx.doi.org/10.1590/S0037-86822001000500013

Domsch K.H., Gams W. \& Anderson T.H., 2007 Compendium of Soil Fungi. $2^{\text {nd }}$ ed., 672 p.

Engel A.S., Stem A.L. \& Bennett P.C., 2004 - Microbial contributions to cave formation: new insights into sulfuric acid speleogenesis. Geology, 32 (5): 369-372. http://dx.doi.org/10.1130/G20288.1

Estrada-Bárcenas D., Palacios-Vargas J.G., EstradaVenegas E., Klimov P.B., Martínez-Mena A. \& Taylor M.L., 2010 - Biological activity of the mite Sancassania sp. (Acari: Acaridae) from bat guano associated with the pathogenic fungus Histoplasma capsulatum. Memoires do Instituto Oswaldo Cruz, 105 (2): 127-131. http://dx.doi.org/10.1590/S0074-02762010000200003

Fernández-Cortés A., Cuezva S., Sanchez-Moral S., Cañaveras J.C., Porca E., Jurado V., Martin-Sanches P.M. \& Saiz-Jimenez C., 2011 - Detection of humaninduced environmental disturbances in a show cave. Environmental Science and Pollution Research, 18: 1037-1045.

http://dx.doi.org/10.1007/s11356-011-0513-5

Ferreira R.L., Nonaka E. \& Rosa C., 2000 - Riqueza e abundância de fungos associados a guano de morcegos na gruta da Lavoura. O Carste, 12 (1): 46-51.

Gompertz O.F., Gambale W., Rodrigues P.C. \& Corrêa B., 2004 - Micologia Especial e Clínica-Micoses Sistêmicas. In: Trabulsi L.R. \& Alterthum F. (Eds.), Microbiologia. $4^{\text {th }}$ ed. São Paulo, SP: Editora Atheneu: 487-493.

Griffin D.H., 1994 - Fungal physiology. New York: Wiley Liss. 427 p.

Guimarães A.J., Nosanchuk J.D. \& Zancopé-Oliveira R.M., 2006 - Diagnosis of Histoplasmosis. Brazilian Journal of Microbiology, 37:1-13. http://dx.doi.org/10.1590/S1517-83822006000100001

Gunde-Cimerman N., Zalar P. \& Jeram S., 1998 Mycroflora of cave cricket Troglophilus neglectus cadavers. Mycopathologia, 141: 111-114.

http://dx.doi.org/10.1023/A:1006947524503

Hsu M. J. \& Agoramoorthy J., 2001 - Occurrence and diversity of thermophilus soil microfungi in forest and cave ecosystems of Taiwan. Fungal Diversity, 7: 27-33

Klich M.A., 2002 - Identification of common Aspergillus species. $1^{\text {st }}$ ed., Centraalbureau voor Schimmelcultures, Utrecht, The Netherlands, $122 \mathrm{p}$.

Koilraj A.J., Marimuthu G., Natarajan K., Saravanan S., Maran P. \& Hsu M.J., 1999 - Fungal diversity inside caves of Southern India. Current Science, 77 (8): 1081-1084.

Kousha M., Tadi R. \& Soubani A.O., 2011 - Pulmonary aspergillosis: a clinical review. European Respiratory Review, 20 (121): 156-174.

http://dx.doi.org/10.1183/09059180.00001011
Lacaz C.S., Porto E., Martins J.E.C.M., Heisvaccari E.M. $\&$ Melo N.T., 2002 - Tratado de Micologia Médica. $9^{\text {th }}$ ed., Sarvier, São Paulo, 1104 p.

Léon M.G.F., López G.A., Taylor M.L., Altamirano G.A. \& Reyes-Monte M.R., 2012 - Development of specific sequence-characterized amplified region markers for detecting Histoplasma capsulatum in clinical and environmental samples. Journal of Clinical Microbiology, 50 (3): 673-679.

http://dx.doi.org/10.1128/JCM.05271-11

Lyon G.M., Bravo A.V., Espino A., Lindsey M.D., Gutierrez R.E., Rodriguez I., Corella A., Carrillo F., McNeil M.M., Warnock D.W. \& Hajjeh R.A., 2004 - Histoplasmosis associated with exploring a bat-inhabited cave in Costa Rica, 1998-1999. American Journal of Tropical Hygiene, 70 (4): 438-442.

Mahvi T.A., 1970 - Factors covering the epidemiology of Histoplasma capsulatum in soil. Mycopathologica et Mycologia Applicata, 41 (1): 167-176. http://dx.doi.org/10.1007/BF02051492

McCarthy C.B., Diambra L.A. \& Pomar R.V.R., 2011 Metagenomic analysis of taxa associated with Lutzomia longipalpis, vector of visceral Leischimaniosis, using an unbased high-throughput approach. PLoS, 5 (9): 1304. 10p.

McClain C.R. \& Barry J.P., 2010 - Habitat heterogeneity, disturbance, and productivity work in concert to regulate biodiversity in deep submarine canyons. Ecology, 91 (4): 964-976. http://dx.doi.org/10.1890/09-0087.1

Nucci M. \& Anaissie E., 2002 - Cutaneous infection by Fusarium species in healthy and immunocompromised hosts: implications for diagnosis and management. Clinical Infectious Diseases, 35: 909-920. http://dx.doi.org/10.1086/342328

Muniz M.M., Pizzini C.V., Peralta J.M., Reiss E. \& ZancopéOliveira R.M., 2001 - Genetic diversity of Histoplasma capsulatum strains isolated from soil, animals, and clinical specimens in Rio de Janeiro state, Brazil, by a PCR-Based Random Amplified Polymorphic DNA Assay. Journal of Clinical Microbiology, 39 (12): 4487-4494. http://dx.doi.org/10.1128/JCM.39.12.4487-4494.2001

Nieves-Rivera Á.M., 2003 - Mycological Survey of Rio Camuy Caves Park, Puerto Rico. Journal of Cave and Karst Studies, 65 (1): 23-28.

Nieves-Rivera Á.M., Santos-Flores C.J., Dugan F.M. \& Miller T.E., 2009 - Guanophilic fungi in three caves of southwestern Puerto Rico. International Journal of Speleology, 38 (1): 61-70.

http://dx.doi.org/10.5038/1827-806X.38.1.7

Novaková A., 2009 - Microscopic fungi isolated from the Domica Cave system (Slovak Karst National Park, Slovakia): a review. International Journal of Speleology, 38 (1): 7182. http://dx.doi.org/10.5038/1827-806X.38.1.8

Pedro E.G. \& Bononi V.L.R., 2007 - Cave fungi of the karst region of the State Touristic Park of the Upper Ribeira Valley (PETAR) in the State of São Paulo in Brazil. Focus, 5: 65-78.

Pitt J.I., 2000. A laboratory guide to common Penicillium species. $3^{\text {rd }}$ ed. Food Science Australia, 197p.

Pfaller M.A. \& Diekema D.J., 2004 - Rare and emerging fungal pathogens: concern for resistance beyond Candida albicans and Aspergillus fumigatus. Journal of Clinical Microbiology, 42 (10): 4419-4431.

http://dx.doi.org/10.1128/JCM.42.10.4419-4431.2004

Porter M.L., Engel A.S., Kane T.C., \& Kinkle B.K., 2009 - Productivity-Diversity relationships from chemolithoautotrophically based sulfidic karst systems. International Journal of Speleology, 38 (1): 27-40. http://dx.doi.org/10.5038/1827-806X.38.1.4

Poulson T. L. \& White W. B., 1969 - The cave environment. Science, 165: 971-980.

http://dx.doi.org/10.1126/science.165.3897.971 
Pulido-Bosch A., 1997 - Human impact in a tourist karstic cave (Aracena, Spain). Environmental geology, 31 (3): 142-149. http://dx.doi.org/10.1007/s002540050173

Resende-Stoianoff M.A., da Silva D.L., Taylor E.L.S., Reis M.F., Magalhaes T.F.F., Martins C.V.B., da Silva C.M., Santos D.A. \& de Fátima A., 2012 - Activity of aldimines against Fusarium solani isolated from bat guano in a neotropical touristic cave. Mycoses, 55 (S1): 102-103.

Ricklefs R. E. \& Schluter D., 1993. Species diversity in ecological communities: historical and geographical communities. University of Chicago Press, Chicago, 414 p.

Samson R.A. \& Frisvad J.C., 2004 - Penicillium subgenus Penicillium: new taxonomic schemes and mycotoxins and other extrolites. Studies in Mycology, $49 \mathrm{p}$.

Sarbu S. M., Kane T. C. \& Kinkle B. K., 1996 - A chemoautotrophically based cave ecosystem. Science, 272: 1953-1955.

http://dx.doi.org/10.1126/science.272.5270.1953

Silveira L.T. 1985 - Isolamento de Microsporum amazonieum do solo da gruta do Piriá (Municipio de Viseu - PA). Belém, Universidade Federal do Pará/Departamento de Biologia, $15 p$. Trabalho de conclusão de curso.

Shapiro J. \& Pringle A., 2010 - Anthropogenic influences on the diversity of fungi isolated from caves in Kentucky and Tennesee. American Midland Naturalist, 163 (1): 76-86. http://dx.doi.org/10.1674/0003-0031-163.1.76

Souza-Silva M., 2008 - Dinâmica de disponibilidade de recursos alimentares em uma caverna calcária. Dissertação de mestrado em Ecologia (Conservação e Manejo da Vida Silvestre), Belo Horizonte: Universidade Federal de Minas Gerais (UFMG).

Takayasu S., Akagi M. \& Shimizu Y., 1977 - Cutaneous mycosis caused by Paecilomyces lilacinus. Archives of Dermatology, 113 (12): 1687-1690.

http://dx.doi.org/10.1001/archderm.1977.01640120055008

Tasic S. \& Tasic N.M., 2007 - Cladosporium spp. - Cause of Opportunistic Mycosis. Acta Facultatis Medicae Naissensis, 24 (1): 15-19.
Trabulsi L.R. \& Alterthum F., 2004 - Microbiologia. $4^{\text {th }}$ ed. Atheneu, São Paulo, SP, 718 p.

Ulloa M., Lappe P., Aguilar S., Park H., Pérez-Mejía A., Toriello C. \& Taylor M.L., 2006 - Contribution to the study of the mycobiota present in the natural habitats of Histoplasma capsulatum: an integrative study in Guerrero, Mexico. Revista Mexicana de Biodiversidad, 77: 153-160.

Unis G., Roesch E. W. \& Severo L.C., 2005 Histoplasmose pulmonar aguda no Rio Grande do Sul. Jornal Brasileiro de Pneumologia, 31 (1): 52-59. http://dx.doi.org/10.1590/S1806-37132005000100010

Vanderwolf K.J., Malloch, D., McAlpine D.F. \& Forbes J., 2013 - A world review of fungi, yeasts, and slime mold in caves. International Journal of Speleology, 42 (1): 77-96. http://dx.doi.org/10.5038/1827-806X.42.1.9

Veraldi S., Chiaratti A. \& Harak H., 2010 - Onychomycosis caused by Aspergillus versicolor. Mycoses, 53 (4): 363-365.

Wang W., Ma X., Ma Y., Mao L., Wu F., Ma X., An L. \& Feng H., 2010 - Seasonal dynamics of airborne fungi in different caves of the Mogao Grottoes, Dunhuang, China. International Biodeterioration and Biodegradation, 64: 461-466. http://dx.doi.org/10.1016/j.ibiod.2010.03.004

Woods J. P., 2002 - Histoplasma capsulatum molecular genetics, pathogenesis, and responsiveness to its environment. Fungal Genetic and Biology, 35: 81-97. http://dx.doi.org/10.1006/fgbi.2001.1311

Yoder J.A., Benoit J.B., Christiensen B.S., Croxall T.J. \& Hobbs H.H., 2010 - Entomopathogenic fungi carried by the cave orb weaver spider, Meta ovalis (Araneae, Tetragnathidae), with implications for mycoflora transer to cave crickets. Journal of Cave and Karst Studies, 71 (2): 116-120.

Zhang L., Muradia G, De Vouge M.W., Rode H. \& Vijay H.M., 1996 - An allergenic polypeptide representing a variable region of hsp 70 cloned from $c D N A$ library of Cladosporium herbarum. Clinical \& Experimental Allergy, 26 (1): 88-95.

http://dx.doi.org/10.1111/j.1365-2222.1996.tb00060.x 